\title{
KEDUDUKAN FATWA DSN-MUI DALAM TRANSAKSI KEUANGAN PADA LEMBAGA KEUANGAN SYARIAH DI INDONESIA
}

\author{
Awaluddin \\ Institut AgamaIslam NegeriBukitinggi,aawal65@yahoo.com \\ Andis Febrian \\ Institut Agama Islam Negeri Bukitinggi, andisfebrian8927@yahoo.com
}

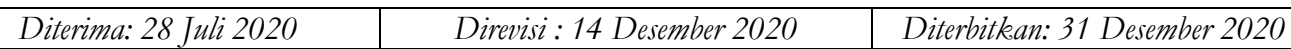

\author{
(c) (i) (2) \\ (C)2020 by the authors. Submitted for possible open access publication under the terms and conditions \\ of the Creative Commons Attribution (CC-BY-SA) license (https://creativecommons.org/licenses/by-sa/4.0/) \\ do) DOI : 10.30983 /alhurriyah.v5i2.3366
}

\begin{abstract}
National Sharia council fatwa is a reference by every sharia financial institution in Indonesia in carrying out its operations. To implement sharia compliance by sharia financial institutions as formed as an extension of the DSN to oversee every financial institution to be in line with sharia principles. A problem that often arises in Islamic financial institutions is that the fatwa issued by DSN requires studies and opinions from DPS in operational techniques in Islamic financial institutions. the existing fatwas bave not yet been represented in technical transactions at financial institutions. This research is a sociological juridical study, which examines the existence of MUI fatwas and the development of sharia economy and how the legal relationship between the MUI fatwa and the implementation of sharia economy in Indonesia with applicable laws and regulations. The results of this study see that the position of the fatwa in the perspective of banking law in Indonesia as a juridical reason for the legislature to set in the legislation. Besides that, the DSN fatwa as a technical basis for supervision is regulated in the laws and regulations on Islamic banking. From the data obtained that the position of fatwa in sharia banking has become a reference in every transaction for the future, each DPS in sharia financial institution is expected to not only be an independent board that is complementary but has a special position and staff in charge of each transaction carried out in the hope of implementing Sharia principles are maximally implemented.
\end{abstract}

Keyword: Fatwa, DSN, Sharia Financial Institutions

\begin{abstract}
Abstrak
Fatwa dewan syariah nasional merupakan rujukan oleh setiap lembaga kenangan syariah di Indonesia dalam menjalankan opersionalnnya. Untuk menjalankan kepatuban syariab oleh lembaga keuangan syariah maka dibentuklah Dewan Pengawas Syariah (DPS) sebagai perpanjangan tangan dari Dewan Syariah Nasional (DSN) untuk mengawasi setiap lembaga keuangan untuk sejalan dengan prinsip syariah. Problem yang sering muncul di lembaga keuangan syariah adalah fatwa yang dikeluarkan oleh DSN membutubkan kajian dan opini dari DPS dalam teknis operasional di lembaga kenangan syariah. Fatwa yang sudah ada belum semuannya terwakili dalam teknis transaksi pada lembaga keuangan. Penelitian ini merupakan suatu penelitian yuridis sosiologis, yaitu meneliti tentang keberadaan Fatwa-fatwa MUI dan perkembangan ekonomi syariah dan bagaimana bubungan bukum antara fatwa MUI dan pelaksanaan ekonomi syariah di Indonesia dengan peraturan perundang-undangan yang berlaku. Hasil penelitian ini melihat bahwa kedudukan fatwa dalam prespektif hukum perbankan di Indonesia sebagai alasan yuridis bagi lembaga legislasi untuk menetapkan dalam aturan perundang-undangan. Disamping itu juga fatwa DSN sebagai dasar teknis pengawasan yang diatur dalam aturan perundang-undangan tentang perbankan syariah. Dari data yang diperoleh bahwa kedudukan fatwa pada perbankan syariah sudah menjadi rujukan dalam setiap transaksi untuk kedepannya setiap DPS yang ada dilembaga kenangan syariah diharapkan tidak hanya sebagai dewan independen yang besifat sebagai pelengkap tetapi memiliki kedudukan dan staf khusus yang membidangi setiap transaksi yang dijalankan dengan harapan pelaksanaan prinsip syariah maksimal dilaksanakan.

Kata kunci: Fatwa, DSN, Lembaga keuangan Syariah
\end{abstract}




\section{PENDAHULUAN}

Fatwa merupakan instrumen hukum yang penting bagi masyarakat muslim di Indonesia dalam menjawab berbagai persoalan sejak zaman kolonial. Dalam cacatan Nico Kaptein selama rentang abad 19 dan 20, produk fatwa yang ada di Indoensia dapat ditemukan dalam tiga bentuk. Pertama, fatwa individu bercorak tradisionalis yang direpresentasikan oleh manuskrip berjudul muhimmat al-nafais fi bayan as'ilat al-hadith, berisi kompilasi fatwa dari beberapa ulama yang sebagian besar dari Syekh Zaini Ahmad Dahlan (w. 1886), mufti Mekah bermadzhab Syafi'i (Kaptein, 1995: 141 142). Kedua, fatwa individu bercorak modernis diwakili oleh buku karya A. Hassan (1887 1958) dengan judul Soal Jawab yang berisi fatwa-fatwa dihimpun dari majalah Pembela Islam periode 1929 - 1935. Ketiga, fatwa komunal yang dikeluarkan oleh organisasi atau lembaga keagamaan seperti hasil bahtsul masail Nahdlatul Ulama (1926), fatwa majelis tarjih Muhammadiyyah (1912), dan juga fatwa Majelis Ulama Indonesia ${ }^{1}$.

Fatwa majlis ulama indonesia telah memberikan konstribusi besar dalam penerapan hukum syariah pada lembaga keuangan semenjak tahun 2000. Sebagai otoritas yang mengeluarkan aturan sebagai rujukan oleh setiap lembaga keuangan di Indonesia, DSN-MUI telah melakukan upaya besar dalam memberikan

${ }^{1}$ Wildan Imaduddin Muhammad, 'Keberanjakan Fatwa Dari LEgal Opinion Menjadi Legal Binding ( Studi Kasus Fatwa DSN MUI Tentang Perbankan Syariah )', Jurisprudensi: Jurnal Ilmu Syariah, Perundang-Undangan Dan Ekonomi Islam, 11.2 (2019), 146-63. legalitas hukum sebagai bahan untuk pengawasan ditingkat dewan pengawas syariah. Berdasarkan aturan yang mengatur lembaga keuangan syariah terutama perbankan syariah berdasarkan UU no 21 tahun 2008, maka setiap perbankan syariah yang menjalankan aktifiatas bisnis harus mendapatkan legalitas formal dalam bentuk fatwa dari DSN-MUI ${ }^{2}$. Hal ini bertujuan untuk mewujudkan keserasian dan kesesuaian transaksi yang dijalankan dengan nilai-nilai syariat Islam. Konstribusi fatwa DSN-MUI sebagai produk hukum telah berjalan pada lembaga keuangan semenjak tahun 2000, tentu pelaksanaan fatwa sebagai wujud nyata oleh pihak lembaga keuangan untuk mewujudkan transaksi bisnis yang merujuk kepada ketentuan syariat Islam. Lembaga keuangan syariah di Indonesia yang semakin hari semakin meningkat tentu tidak hanya bertujuan untuk mencari keuntungan semata tetapi jauh dari pada itu, yaitu untuk mewujudkan keselarasan transasksi dengan prinsip syariat Islam. Tentu sebagai lembaga keuangan syariah diberikan mandat untuk mengembangkan aktifitas dakwah kepada masyarakat melalui kegiatan bisnis yang dijalankan. Keberadaan regulasi tentang perbankan di Indonesia telah melahirkan aturan yang mesti dijalankan oleh setiap lembaga keuangan terutama perbankan syariah. Regulasi yang ada memberikan pengutan dan sinergitas terhadap keberadaan fatwa sebagai bagian yang tak terpisahkan dalam setiap transaksi yang

2 Tuti Hasanah, 'TRANSFORMASI FATWA DEWAN SYARIAH NASIONAL KE DALAM HUKUM POSITIF', Syariah Jurnal Hukum Dan Pemikiran, 2017 < https://doi.org/10.18592/sy.v16i2.1022> 
dijalankan oleh lembaga keuangan syariah di Indonesia $^{3}$

Sebagi upaya dalam pengawasan syariah ditingkat lembaga keuangan syariah maka DSNMUI bekerjasama dengan otoritas jasa keuangan telah menyepakati perlunya dewan pengawas syariah pada masing-masing lembaga keuangan syariah. Hal ini bertujuan untuk memberikan pengawasan serta mendukung setiap program kegiatan yang dijalankan di masing-masing lembaga keuangan syariah supaya sejalan dengan fatwa dewan syariah nasional ${ }^{4}$. Keberadaan DPS di masing-masing lembaga keuangan syariah sengat penting demi terwujudnya pelaksanaan syariah sesuai dengan fatwa yang telah ada. Sejak berdiri tahun 1999, DSN, telah mengeluarkan lebih dari 80 fatwa tentang ekonomi syariah, antara lain, fatwa tentang giro, tabungan, murabahah, jual beli saham, istishna', mudharabah, musyarakah, ijarah, wakalah, kafalah, hawalah, uang muka dalam murabahah, sistem distribusi hasil usaha dalam lembaga keuangan syariah, diskon dalam murabahah, sanksi atas nasabah mampu yang menunda-nunda pembayaran, pencadangan penghapusan aktiva produktif dalam Lembaga Keuangan Syariah, al-qaradh, investasi reksadana syariah, pedoman umum asuransi syariah, jual beli istisna' paralel, potongan pelunasan dalam murabahah, safe deposit box, raha (gadai), rahn emas, ijarah muntabiyah bit

\footnotetext{
3 . Iswahyudi, 'MUI Dan Nalar Fatwa-Fatwa Eksklusif, Al-Ibkam: Jurnal Hukum \& Pranata Sosial, 2017 <https://doi.org/10.19105/al-ihkam.v11i2.785>. 4 'KEDUDUKAN MAJELIS ULAMA INDONESIA (MUI) DAN KOMISI FATWANYA DALAM SISTEM HUKUM TATA NEGARA', ElQUDWAH, 2011.
}

Awaluddin $\mathcal{E}$ Andis Febrian tamlik, jual beli mata uang, pembiayaan pengurusan haji di Lembaga Keuangan Syariah, pembiayaan rekening koran syariah, pengalihan hutang, obligasi syariah, obligasi syariah mudharabah, Letter of Credit (LC) impor syariah, LC untuk ekspor, Sertifikat Wadiah Bank Indoensia, Pasar Uang antar Bank Syariah, sertifikat investasi mudharabah (IMA), asuransi haji, pedoman umum penerapan prinsip syariah di pasar modal, obligasi syariah ijarah, kartu kredit, dan sebagainya ${ }^{5}$.

Permasalahannya adalah apakah para pelaku ekonomi syariah dapat secara langsung menjadikan Fatwa MUI sebagai dasar untuk menerapkan prinsip-prinsip ekonomi syariah ataupun bagi kalangan hakim, apakah Fatwa MUI tersebut dapat dijadikan dasar atau landasan dalam mengambil keputusannya dalam memutus suatu sengketa ataukah fatwa tersebut harus dijadikan atau dituangkan terlebih dahulu ke dalam peraturan perundang-undangan, sehingga diakui keberadaannya dan mempunyai kekuatan hukum mengikat. Mengingat Fatwa MUI tidak termasuk ke dalam jenis peraturan perundang-undangan sebagaimana tersebut dalam Pasal 7 Undang-Undang No. 12 Tahun 2011 tentang Pembentukan Peraturan Perundang-undangan. Permasalahan selanjutnya adalah bagaimana peran dan fungsi Fatwa MUI diperlukan dalam mendorong pelaksanaan ekonomi syariah di Indonesia dan faktor apa saja yang menjadi hambatan dalam penerapan Fatwa MUI. Dari latar belakang permasalahan

5 M Erfan Riadi, 'Kedudukan Fatwa Ditinjau Dari Hukum Islam Dan Hukum Positif (Analisis Yuridis Normatif)', Ulumuddin, 2010. 
tersebut diatas, maka perlu dilakukan penelitian mengenai Kedudukan Fatwa DSN-MUI alam Transaksi Keuangan Pada Lembaga Keuangan Syariah Di Sumatera Barat

\section{METODOLOGI PENELITIAN}

Penelitian ini merupakan suatu penelitian yuridis sosiologis, yaitu meneliti tentang keberadaan Fatwa-fatwa MUI dan perkembangan ekonomi syariah dan bagaimana hubungan hukum antara fatwa MUI dan pelaksanaan ekonomi syariah di Indonesia dengan peraturan perundangundangan yang berlaku. Penelitian ini merupakan penelitian kualitatif deskriptif dengan menggunakan wawancara sebagai alat pengumpulan data. Dokumentasi terkait dengan kedudukan fatwa majelis ulama Indonesia pada lembaga keuangan syariah.

Penelitian ini bersifat deskriptif, yaitu penelitian hukum dimana pengetahuan atau teori tentang obyek sudah ada dan ingin memberikan gambaran tentang obyek penelitian.

Data penelitian yang digunakan dalam penelitian ini berupa data primer dan data sekunder. Data primer yang digunakan yaitu data yang diperoleh langsung dari objek penelitian yang diperoleh melalui cara wawancara kepada pimpinan lembaga keuangan syariah di sumatera barat. Diantaranya bank mandiri syariah cabang kota Padang, BPRS haji Miskin, BPRS Ampek Angkek Canduang, BPRS Al-makmur
Payakumbuh dan Bank Muamalat Indonesia Cabang Bukitinggi.

Terhadap data-data penelitian yang didapatkan akan dianalisa secara kualitatif yang bertujuan untuk mendeskripsikan rumusan jawaban atas permasalahan yang dikemukan dalam penelitian ini.

Bagaimana kedudukan Fatwa DSNMUI dalam perspektif hukum perbankan syariah di Indonesia, dan bagaimana peran fatwa DSNMUI dalam setiap transaksi keuangan syariah pada lembaga keuangan syariah di Sumatera Barat?, serta faktor apa saja yang menjadi hambatan dalam penerapan Fatwa DSN-MUI di lembaga keuangan syariah?

Tujuan dari penelitian ini adalah untuk mengetahui kedudukan Fatwa DSN-MUI dalam perspektif hukum perbankan syariah di Indonesia, peran fatwa DSN-MUI dalam setiap transaksi keuangan syariah pada lembaga keuangan syariah di Sumatera Barat, dan hambatan dalam penerapan fatwa DSN-MUI di lembaga keuangan syariah .

Melalui penelitian ini akan diperoleh data-data hasil penelitian terkait dengan berbagai permasalahan Fatwa MUI sebagaimana tersebut di atas yang diperlukan di masa-masa yang akan datang dalam mendorong pelaksanaan ekonomi syariah guna dijadikan sebagai bahan dalam mendukung pembentukan dan pengembangan hukum di Indonesia.

\section{HASIL PENELITIAN}

\section{Kedudukan Fatwa DSN-MUI dalam perspektif hukum perbankan syariah di Indonesia}

Kedudukan Fatwa DSN.. 
Fatwa adalah sebuah istilah mengenai pendapat atau tafsiran pada suatu masalah yang berkaitan dengan hukum Islam. Fatwa dalam bahasa Arab berarti nasihat, petuah, jawaban atau pendapat. Adapun yang dimaksud adalah sebuah keputusan atau nasihat resmi yang diambil oleh sebuah lembaga atau perorangan yang diakui otoritasnya, disampaikan oleh seorang mufti atau ulama, sebagai tanggapan atau jawaban terhadap pertanyaan yang diajukan oleh peminta fatwa (mustafti) yang tidak mempunyai keterikatan. Penggunaannya dalam kehidupan beragama di Indonesia, fatwa dikeluarkan oleh MUI sebagai suatu keputusan tentang persoalan ijtihâdiyah yang terjadi di Indonesia guna dijadikan pegangan. ${ }^{6}$ Dengan demikian dapat dikatakan bahwa fatwa merupakan salah satu produk hukum Islam atas berbagai permasalahan yang terjadi dan belum pernah ada di zaman Rasulullah SAW. ${ }^{7}$ Sementara itu diketahui bahwa sumber hukum Islam terdiri dari al-Quran, al-Sunnah, dan ra'yu (akal fikiran manusia) dengan berbagai metode diantaranya adalah ijma, qiyas, istibsan, istishab, almasalih al-mursalah, dan 'urf. Ijma' adalah persetujuan atau kesesuaian pendapat para ahli mengenai masalah pada suatu tempat di suatu masa. Dengan demikian fatwa merupakan ketentuan hukum Islam yang diterbitkan berdasarkan pemikiran dan ijtihad dengan cara

6 Sofyan Al-Hakim, 'Perkembangan Regulasi Perbankan Syariah Di Indonesia', Ijtihad: Jurnal Wacana Hukum Islam Dan Kemanusiaan, 2013 <https://doi.org/10.18326/ijtihad.v13i1.15-31>.

7 Irwan Misbach, 'Kedudukan Dan Fungsi Dewan Pengawas Syariah Dalam Mengawasi Transaksi Lembaga Keuangan Syariah Di Indonesia', Fakultas Dakwah Dan Komunikasi UIN Alauddin Makassar, 2014. ijma'. Namun, fatwa tidak sama persis dengan ijma karena didalam ijma telah terjadi kesepakatan/tidak ada perbedaan pendapat atas suatu masalah (yang diminta ataupun tidak diminta). Didalam melaksanakan tugasnya memberikan fatwa, MUI memiliki pedoman dasar dan prosedur yang dirumuskan dalam Keputusan No. U-596/MUI/X/1997 yang ditetapkan pada tanggal 2 Oktober 1997. Untuk memperjelas dasar-dasar dalam memberikan fatwa, berikut rincian dimaksud:

a. Setiap keputusan fatwa harus mempunyai dasar atas kitabullah dan sunnah Rasul yang mu'tabarak serta tidak bertentangan dengan kemashlahatan umat.

b. Jika tidak terdapat dalam Kitabullah dan Sunah Rasul sebagaimana ditentukan pada Pasal 2 Ayat 1, Keputusan Fatwa hendaklah tidak bertentangan dengan ijma, qiyas yang mu'tabar dan dalil-dalil hukum yang lain seperti istibsân, maslahah mursalah dan saddu al dzari'ah.

c. Sebelum pengambilan keputusan fatwa, hendaklah ditinjau pendapat-pendapat para imam madzhab terdahulu, baik yang berhubungan dengan dalil-dalil hukum yang berhubungan dengan dalil yang dipergunakan oleh pihak yang berbeda pendapat.

d. Pandangan tenaga ahli dalam bidang masalah yang akan diambil keputusan fatwanya, dipertimbangkan.

Mencermati peraturan yang dapat dikeluarkan oleh lembaga negara sebagaimana disebut diatas maka fatwa MUI 
tidak merupakan salah satu dari produk Peraturan Perundang Undangan sehingga fatwa MUI bukan peraturan yang mengikat karena MUI merupakan organisasai alim ulama umat Islam dan bukan merupakan institusi milik Negara, bahkan fatwa MUI bukan merupakan hukum negara yang bisa dipaksakan dan tidak memiliki sanksi dan harus ditaati oleh seluruh warganegara. Menurut Mahfud MD, fatwa MUI merupakan pendapat keagamaan, bukan hukum positif yang boleh diikuti dan boleh tidak diikuti sehingga mereka yang melanggar fatwa MUI tidak boleh diberi sanksi atau hukuman. Fatwa itu mengikat pada diri sendiri dan tidak diatur dalam UU. Keberadaan fatwa MUI tidak dapat dipandang sebelah mata. Fatwa yang dilahirkan oleh MUI mendapat dukungan dari umat Islam. Banyak fatwa MUI (dalam hal ini yang dikeluarkan oleh DSN-Dewan Syariah Nasional yang dibentuk oleh MUI pada tahun 1998 berdasarkan SK Dewan Pimpinan MUI No. Kep-754/MUI/II/1999 yang intinya dibentuk dengan tugas dan kewenangan untuk memastikan kesesuaian antara produk, jasa, dan kegiatan usaha bank dengan prinsip syariah) yang telah ditransformasi ke dalam peraturan perundang-undangan seperti Peraturan Bank Indonesia dan Peraturan Otoritas Jasa Keuangan yang dipergunakan untuk mengatur aktivitas ekonomi syariah. Dalam pasal 3 pedoman dasar yang disyahkan dalam musyawarah tahun 1975, disebutkan bahwa
MUI ikut serta dalam memwujudkan masyarakat yang aman dan damai sesuai dengan pancasila dan UUD 1945. Kemudian pada tahun 1990 dibentuknya DSN sebagai salah satu bagian dari MUI untuk memberikan Fatwa yang terkait dengan ekonomi syariah dan sebagai fatner dalam pengawasan lembaga keuangan syariah dengan otoritas Jasa keuangan $(\mathrm{OJK})^{8}$.

Selain itu, saat ini dirasakan bahwa keabsahan produk (khususnya dalam perbankan syariah) belum cukup memadai secara formal maupun substansi untuk mewujudkan kepastian hukum bagi para pihak yang melakukan transaksi?. Transformasi fatwa MUI ke dalam peraturan perundang-undangan sebenarnya bertujuan agar bersifat mengikat dan ditaati bagi seluruh pelaku bisnis syariah, namun dalam kenyataannya banyak fatwa MUI yang belum ditransformasikan kedalam Peraturan Perundang Undangan-pun ternyata telah dijadikan rujukan dan pedoman dalam operasionalisas.

Aktivitas perbankan syariah yang
secara internal dipergunakan atas
rekomendasi dan pengawasan dari DPS
(Dewan Pengawas Syariah) yang ada pada

8 N Hidayah, 'Fatwa-Fatwa Dewan Syariah Nasional Atas Aspek Hukum Islam Perbankan Syariah Di Indonesia', Al-'Adalah, 2011.

9 Andi Fariana, 'Urgensi Fatwa MUI Dalam Pembangunan Sistem Hukum Ekonomi Islam Di Indonesia', Al-Ihkam: Jurnal Hukum \& Pranata Sosial, 2017 <https://doi.org/10.19105/al-ihkam.v12i1.1191>. 
masing-masing bank syariah. $^{10} \mathrm{Hal}$ ini mengingatkan pada konsep hukum yang dibangun oleh Kusumaatmadja bahwa hukum adalah keseluruhan kaedah dan asas yang mengatur kehidupan manusia dalam masyarakat termasuk lembaga dan proses didalam mewujudkan berlakuknya hukum dalam kenyataan. ${ }^{11}$ Selain itu, hal ini menunjukkan bahwa negara nomokrasi yang mencirikan tidak adanya pemisahan antara negara dengan agama dan adanya kebebasan dalam menjalankan agamanya menjadi bukti kuat berlakunya di Negara Kesatuan Republik Indonesia yang berdasarkan atas Ketuhanan Yang Maha Esa.

Fatwa MUI merupakan kaedah dan asas yang dianggap penting dan diperlukan dalam rangka memperlancar aktivitas ekonomi syariah, apakah bentuknya telah ditransformasi kedalam peraturan perundang-undangan ataupun belum ditransformasikan. Cepatnya pertumbuhan bisnis syariah khususnya pertumbuhan perbankan syariah menimbulkan konsekuensi lahirnya berbagai kebutuhan yang berkaitan dengan kejelasan dalam berbagai masalah fiqih dan fatwa MUI merupakan solusi yang dianggap mampu memberikan pedoman dan rujukan. Fatwa memiliki kedudukan yang penting di dalam Hukum Islam walaupun

10 Abdul Khair, 'DINAMIKA PENATAAN REGULASI EKONOMI SYARIAN', El-Mashlahah, 2019 <https://doi.org/10.23971/el-mas.v8i2.1322>.

11 By Admin, 'Perkembangan Fatwa Dewan Syariah Nasional Sebelum Lahirnya UU No. 21 Tahun 2008 Tentang Perbankan Syariah', Thursday, 22 December, 2016.

Awaluddin $\mathcal{E}$ Andis Febrian fatwa bersifat ikhtiyâriyah (tidak mengikat secara legal, mengikat secara moral khususnya bagi mustaftî/pihak yang meminta fatwa). Fatwa merupakan hasil ijtihad kolektif sekalipun demikian fatwa tidak bisa disamakan dengan ijma. Didalam sistem hukum positif, fatwa tidak mengikat dan agar bisa bersifat mengikat maka fatwa harus melewati proses legislasi terlebih dahulu. ${ }^{12}$ Beberapa substansi UU dan Rancangan Undang-Undang disusun dengan melibatkan pemikiran dari para ulama. Salah satunya yang dapat dijadikan contoh adalah UU tentang Wakaf.

\section{Kedudukan fatwa DSN-MUI pada setiap} transaksi keuangan syariah pada lembaga keuangan syariah di Sumatera Barat

Hasil penelitian tentang peran fatwa DSN-MUI pada setiap transaksi keuangan syariah yang berada disumatera Barat dapat dikelompok dalam dua bagian yaitu perbankan syariah seperti bank mandiri syariah cabang bukitinggi, Bank Muamalat cabang Bukitinggi, BPRS haji Miskin kabupaten Tanah Datar dan BPRS Almakmur Kabupaten 50 Kota serta bursa efek Indonesia perwakilan Sumatera Barat. Hasil wawancara vang dilakukan kepada pimpinan Bank Mandiri syariah cabang Kota Bukitinggi menjelaskan bahwa “

12 Mawardi Mawardi, 'Al-'Uqud Al-Murakkabah Sebagai Progresifitas Hukum Ekonomi Syariah Dalam Pengembangan Akad-Akad Perbankan Syariah Di Indonesia, Hukum Islam, 2019 <https://doi.org/10.24014/hi.v18i2.6693>. 
semua produk yang ditawarkan oleb BSM kota Bukitinggi kepada masyarakat telah mendapatkan legalitas formal dari fatwa DSN-MUI ddan sudah dibicarakan secara internal dengan dewan pengawas syariah yang ada di pusat ${ }^{13}$

Secara prinsip semua produk dari BSM yang ada diseluruh Indonesia telah mendapatkan legalitas dari DSN-MUI. Dewan pengawas syariah yang ditempatkan di BSM telah bertugas dalam mengawasi setiap transaksi yang dijalankan. Tetapi dari hasil data yang diperoleh dari responden memberikan beberapa hal yang terkait dengan transaksi yang terdapat di daerah.

Setiap transaksi yang dilaksanakan dikantor cabang terkoneksi langsung kepada kantor pusat yang ada di Jakarta, tetapi ditingkat cabang diperlukan juga diskusi terkait dengan fatwa MUI yang akan dilaksanakan di setiap transaksi jika itu perlu pembahasan dan pejelasan. Maka kami ditingkeat cabang selalu berkomunikasi dengan direksi yang ada dipusat untuk. mendiskusikan hal yang terkait dengan aturan DSN-MUI dalam hal penafsiran. ${ }^{14}$

Bank syariah mandiri merupakan salah satu bank umum syariah yang ada di Indonesia yang telah tersebar diseluruh wilayah di Indonesia. terkait dengan kepengawasan di bidang syariah, Bank syariah mandiri cukup menempatkan DPSnya dan berkantor di kantor pusat BSM. Sedangkan transaksi yang ada di daerah langsung diketahui oleh kantor pusat, maka dalam hal pengawasan tidak menempatkan masing-masing DPS di kantor cabang yang ada di daerah. Dalam hal aplikasi dan penerapan fatwa DSN-MUI di BSM terkait

13 Firman KCP BSM Bukitingi, 'No Title’, 2019, p. wawancara langsung.

14 Bukitinggi.

Awaluddin \& Andis Febrian dengan penafsiran beberapa fatwa yang akan diterapkan di perbankan syariah teruma BSM, hal itu telah dibicarakan dengan DPS bersama direksi dengan tujuan terlaksananya fatwa yang telah digariskan oleh DSN-MUI. Bank syariah mandiri cabang Bukitinggi hanya ditugaskan untuk menjual setiap produk yang diberikan oleh BSM pusat, jadi semua produk yang dijual oleh BSM pusat telah memperoleh kajian dan legalitas dari fatwa DSN-MUI. Sedangkan data yang diperoleh dari bank pembiayaan syariah (BPRS) haji Miskin Pandai Sikek kabupaten Tanah Datar terkait dengan kedudukan fatwa DSN-MUI dalam setiap transaksi keuangan pada bank yang bersangkutan yaitu"

Kedudukan fatwa DSN-MUI di BPRS haji miskin merupakan penentu dalam semua transaksi yang dijalankan seperti fatwa DSN-MUI No 03/DSN-MUI/IV/2000 tentang deposito dan fatwa NO 02/DSN-MUI/IV/2000 tentang tabungan $^{15}$

Penjelasan lain yang diberikan oleh responden terkait dengan kedudukan fatwa DSN-MUI di BPRS Haji Miskin bahwa fatwa merupakan hal yang sangat urgen di lembaga keuangan syariah dikeranakan tujuan bisnis yang dijalankan bukan untuk keuntungan semata tetapi ada tanggung jawab agama yang harus dilaksanakan. Dalam hal ini BPRS belum maksimal dalam memberikan edukasi dan sosialisasi kepada masyarakat tentang fatwa DSN-MUI, makas sebahagian nasabah belum menjadikan bank syariah khususnya

15 direktur BPRS Haji Miskin hendri kamal, 'No Title', 2019, p. wawancara langsung. 203 Kedudukan Fatwa DSN.. 
BPRS sebagai bagian dalam bisnis dan dakwah Islam. Hal ini didasari atas dasar pemahaman nasabah antara bagi hasil dengan bunga belum bisa membedakan dikarenakan latar belakang pendidikan dan pekerjaan.

Sedangkan pada sisi pembiayaan yang disalurkan kedudukan fatwa MUI menjadi hal yang sangat penting, untuk itu DSN sebagai badan pengawas yang ditempatkan dilembaga keuangan syariah khusunya BPRS telah berjalan dengan baik. “

Untuk produk pembiayaan yang dilaksanakan di BPRS haji miskin seperti modal kerja, pembiayaan konsumtif dan investasi, DPS selalu melakukan monitoring terkait dengan pelkasaaan akad dengan transaksi yang dilakukan dengan berpodoman kepada aturan OJK dan fatwa DSN seperti fatwa No 04/DSN-MUI/IV/2000 tentang murabahah, fatwa No 05/DSN-MUI/IV/2000 Akad salam, No 07/DSN-MUI/IV/2000 tentang Mudharabah serta fatwa No No 09/DSN-MUI/IV/2000 ijarah. ${ }^{16}$

Secara prinsip setiap transaksi yang dijalankan telah berpedoman dengan aturan yang ada terutama hal yang terkait dengan komitmen penerapan prinsip syariah di setiap transaksi. Tetapi yang menjadi catatan bagi penelitian adalah dengan jumlah 2 DPS di setiap lembaga keuangan syariah yang mereka dituntut hadir hanya 1 kali dalam satu minggu, apakah sudah maksimal pengawasan yang dilakukan. Kemudian transaksi yang terjadi hanya antara nasabah dengan direksi besrta karyawannya jika terjadi kesalahan dalam pemahaman sedangkan DPS tidak berkantor stiap hari tentu akan memberikan kesulitan tersendiri bagi pihak pengelolah.
Sedangkan pada BPRS Al-Makmur Kabupaten 50 Kota terkait dengan kedudukan fatwa DSN-MUI pada setiap transaksi yang dijalankan ada secara prinsip sesuai dengan yang dijalankan oleh bank syariah yang lain yang ada di Sumatera Barat dan di Indonesia. Untuk akad hiwalah terkait pelayanan kepada nasabah untuk produk take over telah berpedoman kepada fatwa yang telah ada ${ }^{17}$. Dari data yang diperoleh bahwa kedudukan fatwa pada perbankan syariah sudah menjadi rujukan dalam setiap transaksi untuk kedepannya setiap DPS yang ada dilembaga keuangan syariah diharapkan tidak hanya sebagai dewan independen yang bersifat sebagai pelengkap tetapi memiliki kedudukan dan staf khusus yang membidangi setiap transaksi yang dijalankan dengan harapan pelaksaan prinsip syariah maksimal dilaksanakan.

Pada bidang ekonomi, DSN MUI membentuk lembaga perangkat kerja yaitu DSN-MUI yang secara khusus menangani masalah-masalah yang berhubungan dengan aktivitas Lembaga Keuangan Syariah (LKS) dan ekonomi syariah, hal ini tertuang pada SK dewan pimpinan MUI No. Kep754/MUI/II/1999 tertanggal 10 Februari 1999. Tugas dan fungsi DSN-MUI adalah mengeluarkan fatwa tentang ekonomi syariah untuk dijadikan pedoman bagi praktisi dan regulator. Saat ini, DSN-MUI telah mengeluarkan fatwa sebanyak 81 fatwa.
${ }^{16}$ Hendri Kamal.

Awaluddin \& Andis Febrian
${ }^{17}$ Komisaris BPRS Al-Makmur Satriadi Ghafar, 'No Title', 2019, p. wawancara langsung.

Kedudukan Fatwa DSN.. 
Namun, DSN-MUI itu sendiri belum diketahui kekuatan hukum fatwanya dalam hukum positif sehingga dijadikan dasar operasional lembaga keuangan syariah. Namun, tidak sedikit fatwa DSN-MUI yang terserap dalam berbagai peraturan perundang-undangan khususnya di bidang ekonomi syariah pada lembaga keuangan syariah. $^{18}$

\section{Faktor penghambatan dalam penerapan}

\section{Fatwa DSN-MUI di lembaga keuangan} syariah

Hampir seluruh fatwa-fatwa yang dikeluarkan oleh DSN-MUI terserap dalam bentuk Peraturan Bank Indonesia yang akan mengikat seluruh perbankan syariah dan masyarakat pelaku perbankan syariah, namun ada beberapa fatwa yang sulit untuk diterjemahkan dalam peraturan perbankan sehingga hal ini menjadi kendala dalam pengembangan usaha perbankan syariah. Berdasarkan data penelitian yang diperoleh ada beberapa kendala penerapan Fatwa DSN-MUI dalam pelaksanaan perbankan syariah. Dalam hal ini Bank Indonesia mengakui bahwa kendala yang dihadapi yaitu hal yang terkait dengan hukum positif yang berlaku yang sering tidak sejalan dengan hukum Islam. Dalam hukum positif hanya mengenal transaksi utang piutang dalam perbankan, sehingga fatwa MUI terkait

18 Soleh Hasan Wahid, 'Pola Transformasi Fatwa Ekonomi Syariah Dsn-Mui Dalam Peraturan PerundangUndangan Di Indonesia', Abkam: Jurnal Hukum Islam, 2016 < https://doi.org/10.21274/ahkam.2016.4.2.171$198>$.

Awaluddin $\mathcal{E}$ Andis Febrian mudharabah, musyarakah, ijarah dan lainnya tidak dapat dilaksanakan secara utuh. Pihak lembaga perbankan syariah juga mengakui bahwa ada kendala-kendala yang dihadapi dalam penerpan fatwa DSN-MUI, antara lain:

a. Paradigma nasabah yang belum mengenal produk dan operasional perbankan syariah;

b. Regulasi belum selaras dengan fatwa, seperti produk IMBT apabila dilaksanakan sesuai dengan fatwa maka objek IMBT harus atas nama bank, apabila demikian maka akan menimbulkan cost yang tinggi seperti regulasi pajak;

c. Adanya fatwa DSN-MUI yang tidak terlalu detail sehingga untuk hal-hal teknis terkadang menimbulkan pertanyaan/ perdebatan;

d. Adanya fatwa yang belum aplikatif, seperti fatwa DSN-MUI No. 15/DSNMUI/IX/2000 tentang Prinsip Distribusi Hasil Usaha Dalam LKS;

e. Tidak semua fatwa ekonomi relevan dari sisi bisnis. Sebab, LKS tidak akan membuat sebuah produk yang kurang menguntungkan dan tidak dapat diserap oleh pihak ketiga;

f. Kendala Support Pemerintah. Seringkali kebijakan pemerintah menjadi kendala bagi terlaksananya Fatwa DSN-MUI oleh LKS. Misalnya double tax yang pernah diberlakukan untuk akad Murabahah (sebab barang harus dibeli dulu oleh bank dan kemudian baru 
dijual kepada nasabah); Sedangkan kendalakendala yang dihadapi perbankan syariah dalam mengembangkan usahanya berdasarkan persepsi lembaga perbankan syariah:

a. Mindset deposan yang masih berpikir secara konvensional dan masih ada kesan di sebagian masyarakat bahwa bank syariah bersifat ekslusif dalam artian bahwa bank syariah hanya ditujukan untuk masyarakat muslim dan melibatkan kaum yang beragama muslim saja, hal ini dikarenakan sosialisasi perbankan syariah yang belum optimal. Oleh sebab fatwa menggunakan istilah-istilah berbahasa Arab (terutama jenis akad). Selain itu, minimnya budget untuk marketing dan promosi juga menjadi kendala perbankan syariah untuk semakin dikenal di mata masyarakat luas;

b. Peraturan untuk membuat iklim investasi di industri syariah masih kurang fleksibel, aturan perpajakan dan pertumbuhan produk dan jasa baru belum didukung maksimal dengan landasan hukum yang memadai dalam bentuk fatwa DSN-MUI

c. Keterbatasan sumber daya manusia yang memahami produk dan sistem syariah;

d. Masih kurangnya modal yang dimiliki perbankan syariah; e. Lembaga arbitrase syariah nasional yang ada sekarang bukan dibentuk oleh pemerintah tetapi oleh MUI. Hal ini menyebabkan lembaga ini tidak memiliki kewenangan yang mengikat;

f. Fasilitas dari pemerintah terkait penyelesaian pembiayaan bermasalah;

Menurut Yeni Salma Barlinti, kendalakendala dalam penerapan fatwa ekonomi syariah, antara lain disebabkan tidak semua pelaku ekonomi syariah mengetahui adanya fatwa DSN-MUI; masih banyaknya anggapan bahwa fatwa DSN-MUI tidak memiliki kekuatan hukum; fatwa DSN-MUI tidak dapat diterapkan secara sempurna karena adanya hukum-hukum yang telah berlaku yang harus dipatuhi oleh pelaku ekonomi syariah dan masih banyak peraturan perundang-undangan yang belum menunjang pelaksanaan fatwa DSNMUI. Merujuk perihal kendala-kendala sebagaimana tersebut di atas, maka letak permasalahan secara garis besar terletak pada:

b. Proses 'penterjemaahan' atau 'penyerapan' Fatwa DSN-MUI ke dalam peraturan perundang-undangan;

c. Kesiapan pihak perbankan syariah untuk menyesuaikan kegiatan operasional dan produk perbankan mereka dengan Fatwa DSN-MUI;

Berdasarkan kendala-kendala dalam penerapan fatwa DSN-MUI tersebut dalam pelaksanaan ekonomi syariah, maka untuk meminimalkan kendala tersebut yang dapat 
dilakukan antara lain yaitu: perkembangan perbankan syariah yang dinamis tidak diikuti oleh kedinamisan fatwa DSN-MUI yang dapat menjawab kebutuhan perbankan syariah. Oleh karena itu perlunya dilibatkan lebih aktif partisipasi stakeholders salah satunya adalah DSN-MUI dalam setiap penyusunan Fatwa DSN-MUI, sehingga fatwa-fatwa yang dihasilkan dapat menjawab kebutuhan perbankan syariah dan dalam proses 'penterjemaahan' dan 'penyerapan' tidak menimbulkan multitafsir dan dapat langsung diimplementasikan sehingga aspek kehati-hatian dalam kegiatan perbankan syariah dapat terjaga. Peningkatan kualitas sumber daya manusia dari pihak perbankan syariah perlu dilakukan sebagai langkah aktif dari pihak perbankan syariah untuk siap dan faham terhadap prinsip-prinsip perbankan syariah. Hal ini mengingat masih banyak sumber daya manusia dari pihak perbankan syariah yang masih menggunakan perspektif prinsip perbankan konvensional ketika menjalankan perbankan syariah.

Kesimpulan

Dari hasil penelitian yang telah dilakukan terkait dengan kedudukan fatwa DSN MUI dalam setiap transaksi keuangan pada lembaga keuangan syariah di Indonesia dapat dilihat dari beberapa temuan berikut.

Kedudukan Fatwa DSN-MUI dalam perspektif hukum perbankan syariah di Indonesia terlihat dengan Adanya traspormasi fatwa kedalam aturan perundang-undangan, sebagai bagian dalam peningkatan peran dan kedudukan fatwa di setiap transaksi keuangan di lembaga keuangan syariah. Kedudukan fatwa dapat juga terlihat pada rujukan pengawasan lembaga keuangan syariah oleh dewan pengawas syariah yang sudah difatwakan oleh DSN untuk peningkatan pengwasan pada aspek syariah di setiap transaksi keuangan di lembaga pada lembaga keuangan syariah. Fatwa MUI merupakan kaedah dan asas yang dianggap penting dan diperlukan dalam rangka memperlancar aktivitas ekonomi syariah, apakah bentuknya telah ditransformasi kedalam peraturan perundang-undangan ataupun belum ditransformasikan

Kedudukan fatwa DSN-MUI pada setiap transaksi keuangan syariah pada lembaga keuangan syariah di Sumatera Barat. Hasil temuan yang diperoleh dari beberapa direktur BPRS yang ada di Sumatera Barat terkait dengan kedudukan fatwa DSN-MUI. Setiap produk yang ditawarkan oleh lembaga keuangan syariah di Sumatera Barat secara formal sudah memiliki fatwa dari DSN-MUI, sedangkan untuk mengawasi terkait keselarasan fatwa dengan pelaksanaan transaksi sudah dilakukan oleh DPS yang ditempatkan di lembaga keuangan syariah. DPS akan melaporkan kepada DSN sekali dalam 2 tahun terkait dengan hasil pengawasan tersebut.

Faktor apa saja yang menjadi hambatan dalam penerapan Fatwa DSN-MUI di 
lembaga keuangan syariah. Berdasarkan data penelitian yang diperoleh ada beberapa kendala penerapan Fatwa DSN-MUI dalam pelaksanaan perbankan syariah. Dalam hal ini Bank Indonesia mengakui bahwa kendala yang dihadapi yaitu hal yang terkait dengan hukum positif yang berlaku yang sering tidak sejalan dengan hukum Islam. Dalam hukum positif hanya mengenal transaksi utang piutang dalam perbankan, sehingga fatwa MUI terkait mudharabah, musyarakah, ijarah dan lainnya tidak dapat dilaksanakan secara utuh. Regulasi belum selaras dengan fatwa, seperti produk IMBT apabila dilaksanakan sesuai dengan fatwa maka objek IMBT harus atas nama bank, apabila demikian maka akan menimbulkan cost yang tinggi seperti regulasi pajak. Adanya fatwa DSN-MUI yang tidak terlalu detail sehingga untuk hal-hal teknis terkadang menimbulkan pertanyaan/ perdebatan. Adanya fatwa yang belum aplikatif, seperti fatwa DSN-MUI No. 15/DSN-MUI/IX/2000 tentang Prinsip
Distribusi Hasil Usaha Dalam LKS. Kendala Support Pemerintah. Seringkali kebijakan pemerintah menjadi kendala bagi terlaksananya Fatwa DSN-MUI oleh LKS. Misalnya double tax yang pernah diberlakukan untuk akad Murabahah (sebab barang harus dibeli dulu oleh bank dan kemudian baru dijual kepada nasabah). Mindset deposan yang masih berpikir secara konvensional dan masih ada kesan di sebagian masyarakat bahwa bank syariah bersifat ekslusif dalam artian bahwa bank syariah hanya ditujukan untuk masyarakat muslim dan melibatkan kaum yang beragama muslim saja, hal ini dikarenakan sosialisasi perbankan syariah yang belum optimal. Oleh sebab fatwa menggunakan istilah-istilah berbahasa Arab (terutama jenis akad). Selain itu, minimnya budget untuk marketing dan promosi juga menjadi kendala perbankan syariah untuk semakin dikenal di mata masyarakat luas.

\section{DAFTAR KEPUSTAKAAN}

Al-Hakim, Sofyan, 'Perkembangan Regulasi Perbankan Syariah Di Indonesia', Ijtihad: Jurnal Wacana Hukum Islam Dan Kemanusiaan, 2013 < https:// doi.org/10.18326/ijtihad.v13i1.15-31>

Firman KCP BSM, 'No Title', 2019, p. wawancara langsung, Bukitinggi

By Admin, 'Perkembangan Fatwa Dewan Syariah Nasional Sebelum Lahirnya UU No. 21 Tahun 2008 Tentang Perbankan Syariah', Thursday, 22 December, 2016

Fariana, Andi, 'Urgensi Fatwa MUI Dalam Pembangunan Sistem Hukum Ekonomi Islam Di Indonesia', Al-Ibkam: Jurnal Hukum \& Pranata Sosial, 2017 <https://doi.org/10.19105/alihkam.v12i1.1191>

Hasanah, Tuti, 'Transformasi Fatwa Dewan Syariah Nasional Ke Dalam Hukum POSITIF', Syariah Jurnal Hukum Dan Pemikiran, 2017 <https://doi.org/10.18592/sy.v16i2.1022>

Hendri Kamal, direktur BPRS Haji Miskin, 'No Title', 2019, p. wawancara langsung

Hidayah, N, 'Fatwa-Fatwa Dewan Syariah Nasional Atas Aspek Hukum Islam Perbankan Syariah Di 
Indonesia', Al-'Adalah, 2011

Iswahyudi, ., 'MUI Dan Nalar Fatwa-Fatwa Eksklusif, Al-Ihkam: Jurnal Hukum \& Pranata Sosial, 2017 < https://doi.org/10.19105/al-ihkam.v11i2.785>

'Kedudukan Majelis Ulama Indonesia (Mui) Dan Komisi Fatwanya Dalam Sistem Hukum Tata Negara', El-Qudwah, 2011

Khair, Abdul, 'Dinamika Penataan Regulasi Ekonomi Syarian', El-Mashlahah, 2019 $<$ https://doi.org/10.23971/el-mas.v8i2.1322>

Mawardi, Mawardi, 'Al-'Uqud Al-Murakkabah Sebagai Progresifitas Hukum Ekonomi Syariah Dalam Pengembangan Akad-Akad Perbankan Syariah Di Indonesia', Hukum Islam, 2019 $<$ https://doi.org/10.24014/hi.v18i2.6693>

Misbach, Irwan, 'Kedudukan Dan Fungsi Dewan Pengawas Syariah Dalam Mengawasi Transaksi Lembaga Keuangan Syariah Di Indonesia', Fakultas Dakwah Dan Komunikasi UIN Alauddin Makassar, 2014

Muhammad, Wildan Imaduddin, 'Keberanjakan Fatwa Dari LEgal Opinion Menjadi Legal Binding ( Studi Kasus Fatwa DSN MUI Tentang Perbankan Syariah )', Jurisprudensi: Jurnal Ilmu Syariah, Perundang-Undangan Dan Ekonomi Islam, 11.2 (2019), 146-63

Riadi, M Erfan, 'Kedudukan Fatwa Ditinjau Dari Hukum

Islam Dan Hukum Positif (Analisis Yuridis Normatif)', Ulumuddin, 2010

Satriadi Ghafar, Komisaris BPRS Al-Makmur, 'No Title', 2019, p. wawancara langsung

Wahid, Soleh Hasan, 'POLA Transformasi Fatwa Ekonomi Syariah Dsn-Mui Dalam Peraturan Perundang-Undangan Di Indonesia', Abkam: Jurnal Hukum Islam, 2016 <https://doi.org/10.21274/ahkam.2016.4.2.171-198> 